\title{
THE SPECIFICS OF THE CULTURAL IMPACT OF THE RESORT ON THE SURROUNDING AREA
}

\author{
(C) Olga M. Zatesova
}

\author{
Khabarovsk Technology College, Khabarovsk, Russian Federation \\ olgazhs@rambler.ru
}

The article is devoted to the study of the experience of the Kuldur resort in the formation of a special socio-cultural environment of the adjacent territory. The specificity of the cultural impact of the resort on the adjacent populated area has been investigated. Sources on the history of Far Eastern health resorts, balneology, materials of the Far Eastern press of the late 19th - early 20th centuries were collected, a number of archival documents were considered, allowing to draw up a comprehensive picture of the cultural influence on the territory. It was revealed that the Kuldur resort, which arose in the taiga, was initially in difficult conditions: remoteness from big cities, unfavorable climate, lack of attractions. The health resort was faced with the task of organizing a good rest for patients with cultural leisure. This task cannot be accomplished without trained personnel. Therefore, the young health resort, in addition to the general utilitarian function of improving the population, acted as an organizer of the cultural and educational environment for the population of the adjacent residential area. The resort passed this test and until 1991 was engaged in the organization of cultural programs for the population, much attention was paid to the aestheticization of the territory of the resort and settlement, work with personnel, scientific and educational activities, the development of the creative potential of the individual. Today shows that without a dynamic well-coordinated work with the staff and the population, the area itself and the resort fell into decay. It is concluded that the positive experience of the Kuldur resort can be applied in other resort areas of the Far East.

Key words: resort, Far Eastern health resort, socio-cultural influence, cultural and leisure activities.

\section{[O.M. Затесова Специфика культурного воздействия курорта на прилегающую территорию]}

Статья посвящена изучению опыта курорта Кульдур в формировании особой социокультурной среды прилегающей территории. Исследована специфика культурного воздействия курорта на прилегающую населённую местность. Собраны источники по истории дальневосточных здравниц, бальнеологии, материалы дальневосточной прессы конца XIX - начала XX в., рассмотрен ряд архивныX документов, позволяющих составить комплексную картину культурного влияния на территорию. Выявлено, что курорт Кульдур, возникший в тайге, был изначально в трудных условиях: отдалённость от больших городов, неблагоприятный климат, отсутствие достопримечательностей. Перед здравницей стояла задача - организация полноценного отдыха пациентам с культурным досугом. Данную задачу невозможно реализовать без подготовленного персонала. Поэтому молодая здравница, помимо общеутилитарной функции - оздоровление населения, выступала в роли организатора культурнообразовательной среды для населения прилегающей к нему жилой территории. Курорт выдержал это испытание и вплоть до 1991 г. занимался организацией культурных программ для населения, большое внимание уделялось эстетизации территории курорта и поселения, работе с персоналом, научно-просветительской деятельности, развитию творческого потенциала личности. Сегодняшний день показывает, что без динамичной слаженной работы с персоналом и населением, сама местность и курорт пришли в упадок. Сделан вывод, что положительный опыт работы курорта Кульдур может быть применим в других курортных местностях Дальнего Востока

Ключевые слова: курорт, дальневосточная здравница, социокультурное влияние, культурнодосуговая деятельность

Olga M. Zatesova - teacher, Khabarovsk Technology College, Khabarovsk, Russian Federation.

Затесова Ольга Михайловна - преподаватель, Хабаровский технологический колледж, г. Хабаровск, Российская Федерация. 
At the present stage of Russia's economic development, issues of a sociocultural nature have become topical again. Currently, the Government of the Russian Federation pays special attention to the Far East, where a wide range of measures are being taken to diversify the growth of the region. A special place in the list of implemented tasks is given to the work on the revival of old and the creation of new medical and recreational tourist centers based on thermal waters and therapeutic mud [10], where resorts can become not only recreational centers, but also the basis for the cultural development of territories. We would like to note that during the heyday of the resort system of the country, which fell on the Soviet era, many resorts of the Far Eastern region became not only recreational centers, but also sources of cultural development of the surrounding area, which is especially typical for taiga resort areas of the Far East.

Many works of outstanding doctors such as I.A. Bogashev, F.F. Fomina, E.G. Chulkov and others $[5,12,14]$ where the object of research is natural healing factors as mud, mineral waters. The issues of the development of local resorts are touched upon in the works of the historian and ethnographer V.A. Chernov [13]. However, there are no works devoted to a comprehensive study of the influence of the Far Eastern resort on the cultural development of the area.

We used archival materials, memoirs of contemporaries who lived on the territory of the village in the period from the 30 s to the 80 s of the $20^{\text {th }}$ century as well as a number of interviews were conducted with the senior residents of the village. To objectify the information received and to conduct a critical comparison of sources, hermeneutic analysis was used. In studying the initial conditions for the development of resorts and identifying the main stages of development, the author used a genetic method.

The history of the development of the region's resorts is directly related to the development of the Amur River region (in different years, the Amur, Zabaykalsky, Primorsky regions were a part of the Priamurskiy krai(frontier)). The stages of development of the resort system of the Amur Territory are divided by the author on the basis of the general historical development of the region, as follows:

I. Discovery and exploration of the resort area (from 1860 to 1918), the time of intensive development and settlement of the lands of the Amur region;

II. Development and establishment of full-fledged health resorts (from 1923 to 1941), the change of the state system and the new health policy directly influenced the development of resorts;

III. War and post-war period (1941-1956), during the war years many resorts were transformed into rear hospitals, after the war they were sorely lacking funding;

IV. Revival and transformation (1956-1991), the management of the resorts was transferred to the All-Union Central Council of Trade Unions (hereinafter - the VTsSPS). One-man management made it possible to expand the region's sanatorium-resort network, improve the material and technical base and stabilize financing.

From the middle of the $21^{\text {th }}$ century to the beginning of the $20^{\text {th }}$ centuries, in the Amur region, the resettlement campaign intensified, which negatively affected people's health. The population, suffering from many ailments in the absence of any medical assistance, had to independently seek remedies. Healing was found in mineral springs. The development of resort areas took place on the initiative "from below" [13, p. 92], that is, by the forces of the population, which saw the potential of a natural healing factor. However, the provincial authorities practically did not allocate funds for the construction of the resort.

The change in the political system as a result of the Revolution had a positive effect on the development of resorts. The young Soviet state had the task of organizing a health care system to treat the broad masses. In the period from 1923 to 1937. the main resorts of the region were created: Kuldur, Shmakovka, 19 kilometre, Talaya. The Great Patriotic War suspended the development of health resorts for a decade and a half. The situation 
began to improve after the transfer of resorts and sanatoriums to the jurisdiction of the VTSSPS (1956): the territories were improved, the capacity increased, the living conditions of vacationers improved, the infrastructure was established [11, pp. 54-55].

Despite the fact that the Far East is rich in mineral springs, there are few resorts here. This is due to the fact that many areas of the outlet of mineral waters are located in the permafrost zone, in rocks (which complicates their extraction), most of the territory is a harsh climate with an average annual temperature of $-2^{\circ} \mathrm{C}$. In addition, many springs have a small daily debit of water [8, p. 2]. The Kuldur resort area is an example of a combination of factors that contributed to the establishment of a health resort. The first mention of the Kuldur spring appeared in the press in 1897, in the newspaper Priamurskie vedomosti: "... 15 miles from the mouth of the Kuldur there are hot waters, the study and analysis of which were carried out by Mr. Batsevich ..." [4]. The arrangement of the resort area was carried out by the forces of workers who lost their health during the construction of railways. However, the source quickly gained popularity among the population and soon became a place of healing for everyone.

Before the revolution, it was a primitive settlement on the waters: huts, dugouts, dirt baths and a canopy as a dining room. The development of the health resort began only after the end of the Civil War and the establishment of Soviet power in the Far East. In 1923, Kuldur was officially awarded the title of a resort and it was transferred to the jurisdiction of the Far Eastern Resort Administration (hereinafter - FERA) [6, p. 262]. Immediately after the transfer to FERA, the first social facilities appeared: a paramedic station, a pharmacy, an outpatient clinic. In order to expand the resort, FERA bought houses near springs from the local population - the first housing stock of the resort, the owners themselves settled near the resort and formed the current village of Kuldur. The social composition of the Kuldur settlement in the first years of the founding of the resort is represented by four main groups of the population:

1) Nanaians, Evenkis in small numbers;

2) disabled workers who have lost their health on building facilities;

3) wounded Red Army men and former partisans;

4) a small group of Chinese from among those who moved to Russia during the Russo-Japanese War.

However, the new health resort under construction was an attractive fast-growing labour market. Various strata of the population flocked here, mainly the Far Eastern peasantry and proletariat. It was not a simple contingent, they could not work at the resort, engage in patient care for obvious reasons, i.e. the lack of the necessary level of training, the difference in mentality and cultural level. Young people capable of learning and mastering this profession were recruited to the mid-level medical personnel. The social section of the first vacationers in the early years was represented by the following groups: workers, educators and employees in art, military personnel, peasants [3, pp. 22-25]. Both vacationers and resort workers would probably never have met in ordinary out-of-resort life due to mental and professional differences, but they did meet in a place of short-term residence a resort. In addition to the general utilitarian function of the resort, i.e. improving the population, it needed to organize leisure and recreation in such a way that it favored recovery, it was required to "grow" personnel for the resort from among the local population for such a complex, responsible work - human service.

In other words, the population needed to be educated, introduced to culture, to the modern realities of the new Soviet era. At the beginning, the Kuldur resort faced a difficult problem - the solution of the staff shortage. Based on such difficult circumstances as remoteness from large settlements, an acute shortage of educated qualified personnel, the resort, as an enterprise attracted the local population. The scheme of the resort's activities as a cultural and educational environment is shown in Figure 1. 


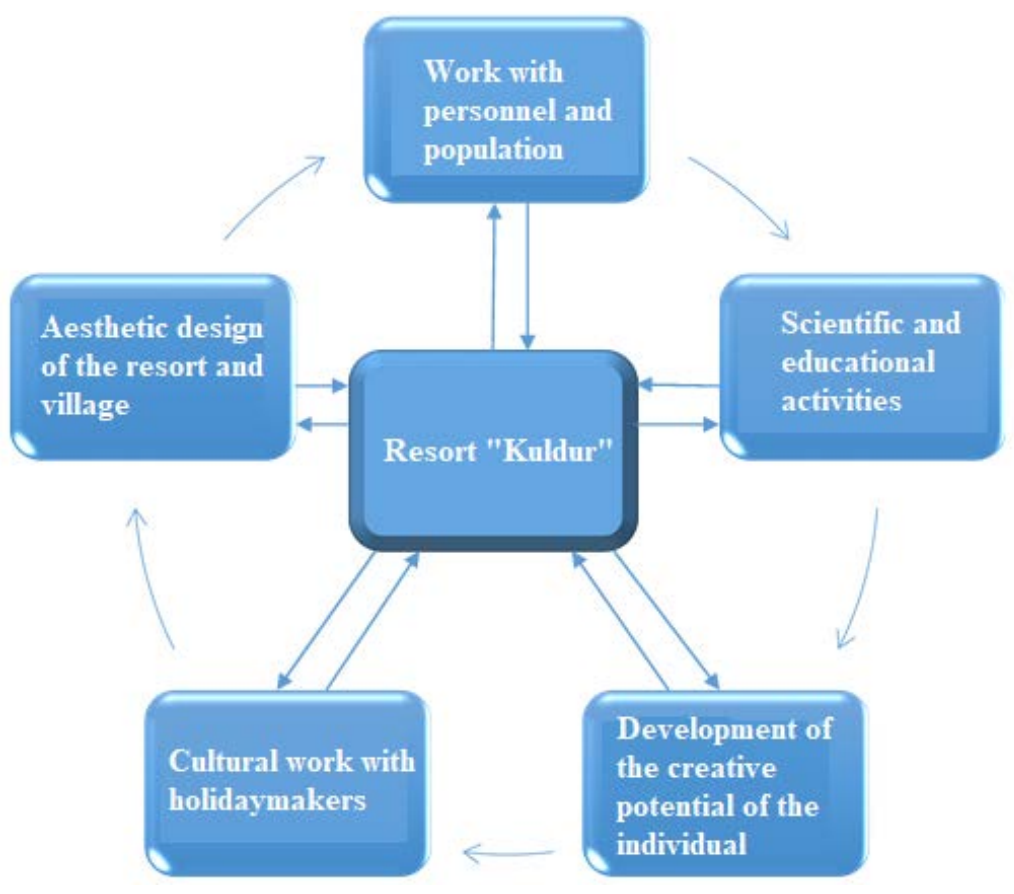

Figure 1. Scheme of the resort's activities as a cultural and educational environment.

The resort did not immediately become a cultural and educational environment for the population. Many functions were added with the development of the health resort, filling its infrastructure. The development of cultural and social functions for such health resorts is natural, since the taiga resorts have a number of specific features: 1) a lack of attractions, the absence of significant historical events, which is what the resorts of the Caucasus and the Black Sea coast are so rich in; 2) the absence of nearby cities where you can go in your free time from treatment; 3) forced constant interaction with the staff and the local population, since the resort enterprise itself is located within the boundaries of a residential area.

With regard to the Kuldur resort, absolutely all areas of activity in this area were interconnected.

The organization of leisure for holidaymakers required trained personnel and not just a trained cultural workers, but creative professionals who loved their job and this area. Such a specialist cannot be "got" from the university, one must be raised in this area. Specialists were raised through work with staff and the public. In such a closed place, it is impossible to separate the personnel of the resort from the population, because the population was made up of the families of the employees of the resort and their relatives. Consequently, there are no conditions for working only with personnel; family members, the population of the village, were involuntarily involved in this process. By the end of the 1970s, the resort managed to organize high-quality cultural work [2, pp. 86-88]. Kuldur built a large concert hall, where at different times famous artists and theater companies performed: T. Miansarova, V. Obodzinsky, B. Shtokolov, K. Beldy, R. Ibragimov, Moscow Maly Theater [7]. The high culture of the best representatives of the national scene became available to residents. Everyone could come to the concert - both holiday-makers and the local population. There was no privileged attitude towards anyone. On a regular day, the club stage was not empty. There were choral, vocal and drama circles in the club, where the population could realize their creative potential, because not only employees, but also residents of the Kuldur village were invited there. The choir, which included 90 people, has become the hallmark of the resort. It has repeatedly become the winner in the 
review contests of resort groups among the health resorts of the RSFSR [1. D. 4.L. 1-8; L. 23; L. 36].

Work with the population was carried out through searching and developing of an individual creativity and the organization of children's leisure. First of all, leisure was organized for the little patients of the sanatorium: creative groups, workshops, and amateur performances. The children of the village were willingly involved in this activity. The child revealed his/her talents, and the resort received a grateful and loyal parent - an employee. In order to reveal the creative potential of an adult, competitions of professional skills, exhibitions of folk craftsmen and craftswomen were organized; the population was involved in cultural work, in beautification and aestheticization of the territory. Moreover, "beautification of the territory" does not mean the standard Soviet «subbotniks» (a community work day), but the creative and professional realization of the potential of the individual. Thus, by the efforts of folk craftsmen, the inner walls of children's buildings were painted, openwork pavements, fences with taiga motives were erected [2, pp. 88-90].

Scientific and educational activities were necessary for the qualitative and effective performance of the main function, that is the improvement of the population, as well as the introduction of new forms and methods of treatment based on the Kuldur mineral water. Scientific activity consisted in the following: on the basis of the enterprise an experimental laboratory was created to study the properties of water, in which the leading Far Eastern balneologists and local doctors worked, on the basis of work in the laboratory, candidate and doctoral dissertations were defended, Kuldur was the initiator and host of scientific and practical conferences. We should also mention the promotion of educational activities. The first school was built by the resort (1924), teachers from different parts of the country were sent to teach children. The task of the resort was to create favorable conditions for teachers to live: apartments were built, communications were laid, and leisure was organized. Results were not long in coming. The author now has access to the memoirs of one of the first graduates of the school of historian and ethnographer N.P. Sergodeeva about the first graduates: "... Many of them died at the front, those who were lucky enough to survive continued to work for the good of their homeland - Counter Admiral N. F. Khanin, Director of the Research Institute of Traumatology and Orthopedics (Irkutsk) T.D. Zyryanova, as well as future doctors and teachers of the village..." [9, p. 5].

The experience of the Far Eastern Kuldur resort is unique in terms of work with the population and lies in the fact that, firstly, there was not a single city or large settlement nearby that could extend its influence over the area, as the cities of Khabarovsk and Vladivostok influenced the nearby resorts. Secondly, in a very short period of time, a society capable of interacting with holidaymakers was formed. Thirdly, realizing the importance of educating society in the absence of any infrastructure, auxiliary facilities, the resort itself took on this task and realized it, becoming a desired place of work, a desired place of rest.

The Kuldur area and the resort is a unique case in the galaxy of Far Eastern resorts, where the historical and cultural development of the area began from the moment the source was discovered in the absence of the influence of large settlements, where the culture of the area and society was formed due to the objective need to deploy a full-fledged resort to meet the needs of the region in the improvement of the population. The development of the resort has led to the development of culture. For the sake of fairness, we note that in Soviet times, many villages grew up around the deposits of any minerals and the factories built with them, and, inevitably, cultural institutions appeared there: clubs, circles, museums, etc. But, if culture in such places was a kind of auxiliary link, as a form of spending leisure time for a working person, then the culture of a resort area is one of the elements on which the resort was based. 


\section{Лumepamypa}

1. ГАХК. Ф. Р-2004 Оп. 1 Материалы Хабаровского территориального совета по управлению курортами профосоюзов. Д. 1, Д2, Д. 4, Д. 4а, Д. 8, Д. 13, Д. 16, Д. 18, Д. 19, Д. 25, Д. 30, Д. 31, Д. 36, Д. 37, Д. 43, Д. 49, Д. 69, Д. 103, Д. 105

2. Завгорудько В.Н. Кульдур - испытание на прочность (хроники главного врача). Хабаровск: Дальневосточный гос. мед. университет, Хабаровское краевое отделение Русского географического общества, 2019. 237 с.

3. Игошин В.А. Кульдур. М.: Объединение государственных книжно-журнальных издательств, 1934. 44 с.

4. Кульдурский минеральный горячий источник // Приамурские ведомости. 1917. № 2548.

5. Курорты Дальнего Востока / по ред. И.А. Багашева, М.: Изд. Дальне-Восточного Курортного Управления, 1923. $65 \mathrm{c.}$

6. Курорты СССР / под ред. С.В. Крушанова, Н.Е. Хрисанова, Л.Г. Гольдфайля. М.: Государственное издательство медицинской литературы Медгиз, 1951. 504 с.

7. Пуэн Г.А. Беседа о культурно-массовой работе курорта Кульдур в 1960-80-е гг. [беседу провела Затесова О.М. 07.07.2020].

8. Рогальский В.Н. Отчёт Кульдурской экспедиции 1938 г. М.: Центральный институт курортологии, 1939. Т.1. 52 с.

9. Сергодеев Н.П. Воспоминания о кульдурской школе. Кульдур, 1998. 30 с.

10. Стратегия социально-экономического развития Дальнего Востока и Байкальского региона на период до 2025 года, утверждённая Распоряжением Правительства PФ от 28.12.2009 г. N 2094 р [Электронный ресурc]. URL: http://www.consultant.ru/document/cons_doc_LAW_96571/f1d12cbe15c5cdddbd0ac6 1a818831f10e1f7c4d/ (дата обращения: 03.04.2020).

11. Улицкий Л. Курорты и санатории Южного Приморья. Владивосток, 1957. 63 c.

12. Фомин Ф.Ф. Курорты Дальнего Востока. Владивосток: Дальневосточное книжное издательство, 1978. 192 с.

13. Чернов В.А. История становления гостиничного дела на Востоке Российской империи. Хабаровск: Изд-во ДВГУПС, 2012. 231 с.

14. Чулков Е.Г. Дальневосточные здравницы. Хабаровск, 1971. 190 с

\section{References}

1. State Archives of the Khabarovsk Territory. Fund. R-2004 Op. 1 Materialy Khabarovskogo territorial'nogo soveta po upravleniyu kurortami profsoyuzov [Materials of the Khabarovsk Territorial Council for the Management of Trade Unions Resorts]. D. 1, D2, D. 4 , D. 4 a, D. 8 , D. 13 , D. 16 , D. 18 , D. 19 , D. 25 , D. 30 , D. 31 , D. 36 , D. 37 , D. 43 , D. 49 , D. 69 , D. 103 , D. 105 (In Russian).

2. Zavgorudko, V.N. Kuldur - ispytaniye na prochnost (khroniki glavnogo vracha). [Kuldur - a test of strength (chronicles of the chief physician)]. Khabarovsk: Dalnevostochnyy gos. med. universitet, Khabarovskoye krayevoye otdeleniye Russkogo geograficheskogo obshchestva, 2019. 237 p. (In Russian).

3. Igoshin V.A. Kuldur [Kuldur]. Moscow: Obyedineniye gosudarstvennykh knizhnozhurnalnykh izdatelstv, 1934. 44 p. (In Russian).

4. Kuldur mineral hot spring [Kuldur mineral hot spring]. Priamurskie vedomosti. 1917. No. 2548. (In Russian). 
5. Kurorty Dalnego Vostoka [Resorts of the Far East]. Moscow: Izdatelstvo DalneVostochnogo Kurortnogo Upravleniya, 1923. 65 p. (In Russian).

6. Kurorty SSSR [Resorts of the USSR]. Moscow: Gosudarstvennoye izdatelstvo meditsinskoy literatury Medgiz, 1951. 504 p. (In Russian).

7. Puen G.A. Beseda o kulturno-massovoy rabote kurorta Kuldur v 1960-80-ye gg. (besedu provela Zatesova O.M. 07.07.2020) [Conversation about the cultural work of the Kuldur resort in the 1960s - 80s (the conversation was conducted by O.M. Zatesova, 07 July 2020)] (In Russian).

8. Rogalskiy V.N. Otchot Kuldurskoy ekspeditsii $1938 \mathrm{~g}$. [Report of the Kuldur expedition in 1938]. Moscow: Tsentralnyy institut kurortologii, 1939. V.1. 52 p. (In Russian).

9. Sergodeev N.P. Memories of the Kuldur school [Memories of the Kuldur school.]. Kuldur, 1998. 30 p. (In Russian).

10. Strategiya sotsialno-ekonomicheskogo razvitiya Dalnego Vostoka i Baykalskogo regiona na period do 2025 goda, utverzhdonnaya Rasporyazheniyem Pravitelstva RF ot 28.12.2009 g. N 2094-p [The strategy of socio-economic development of the Far East and the Baikal region for the period up to 2025, approved by the Order of the Government of the Russian Federation of December 28, 2009 N 2094-p]. Available at: http://www.consultant.ru/document/cons_doc_LAW_96571/f1d12cbe15c5cdddbd0ac6 1a818831f10e1f7c4d/ (accessed 03 April 2020) (In Russian).

11. Ulitskiy L. Kurorty i sanatorii Yuzhnogo Primorya [Resorts and sanatoriums of South Primorye]. Vladivostok, 1957. 63 p. (In Russian).

12. Fomin F.F. Kurorty Dalnego Vostoka [Resorts of the Far East]. Vladivostok: Dalnevostochnoye knizhnoye izdatelstvo, 1978. 192 p. (In Russian).

13. Chernov V.A. Istoriya stanovleniya gostinichnogo dela na Vostoke Rossiyskoy imperii [The history of the formation of the hotel business in the East of the Russian Empire]. Khabarovsk: Izdatelstvo DVGUPS. 2012. 231 p. (In Russian).

14. Chulkov Ye.G. Dalnevostochnyye zdravnitsy [Far Eastern health resorts]. Khabarovsk. 1971. 190 p. (In Russian). 